\title{
JOURNAL.RU
}

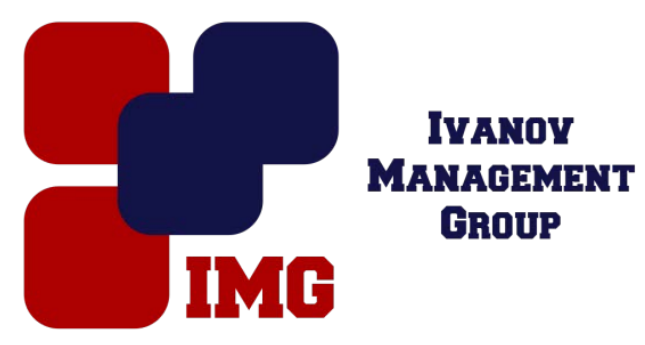

Токарева К.Г., Сафиуллина А.Ф. Набережночелнинский филиал ЧОУ ВО «Казанский инноващионный университет им. В.Г. Тимирясова (ИЭУП)》 Набережные Челны, Россия

doi: 10.18411/lj-30-11-2016-3-14

idsp 000001:lj-30-11-2016-3-14

\section{Правовые последствия нарушения договора возмездного оказания медицинских услуг}

\section{Аннотация}

Статья посвящена рассмотрению правовых последствий некачественного оказания медицинских услуг. Сделан вывод, что исполнитель в силу особенностей предмета договора возмездного оказания медицинских услуг несет повышенную ответственность.

Ключевые слова: договор возмездного оказания медицинских услуг, медицинские услуги, моральный вред, «врачебная ошибка»

Пациент вправе требовать от исполнителя возмещения причиненного ему вреда как материального, так и морального. Возмещение вреда (ущерба) состоит в выплате потерпевшему денежной суммы, которую он произвел или должен будет произвести для восстановления нарушенного здоровья, а также в возмещении упущенной выгоды и морального вреда. Размер такого возмещения зависит от величины расходов, затраченных на лечение потерпевшего, результата лечения (выздоровление, хронизация полученного заболевания или травмы, инвалидность, смерть). Также учитывается сумма утраченного им заработка (дохода) в связи с болезнью.

В Постановлении «Некоторые вопросы применения законодательства о компенсации морального вреда» Пленум Верховного Суда РФ определил, что под моральным вредом следует понимать нравственные или физические страдания, причиненные действиями (бездействием), посягающими на принадлежащие гражданину от рождения или в силу закона нематериальные блага (жизнь, здоровье, достоинство личности, деловая репутация, неприкосновенность частной жизни, личная и семейная тайна и т.п.) или нарушающими его личные неимущественные права (право на пользование своим именем, право авторства и другие неимущественные права в соответствии 
с законами об охране прав на результаты интеллектуальной деятельности) либо нарушающими имущественные права гражданина.

Моральный вред, в частности, может заключаться в нравственных переживаниях в связи с утратой родственников, невозможностью продолжать активную общественную жизнь, потерей работы, раскрытием семейной, врачебной тайны, распространением не соответствующих действительности сведений, порочащих честь, достоинство или деловую репутацию гражданина, временным ограничением или лишением каких-либо прав, физической болью, связанной с причиненным увечьем, иным повреждением здоровья либо в связи с заболеванием, перенесенным в результате нравственных страданий и др.

Термин «страдание» предопределяет, что действия причинителя морального вреда обязательно должны проявиться в сознании потерпевшего, вызвать определенную психическую реакцию. При этом вредоносные изменения в охраняемых благах выражаются в сознании в форме ощущений (физические страдания) и представлений (нравственные страдания). Наиболее близким к понятию «нравственные страдания» следует считать понятие «переживания». Содержанием переживаний может являться страх, стыд, унижение, иное неблагоприятное в психологическом аспекте состояние.

Согласно ст. 15 Закона «О защите прав потребителей» моральный вред возмещается исполнителем в случае нарушения прав потребителей. Кроме того, моральный вред должен быть возмещен согласно ст. 1099-1101 ГК РФ, ст. 151 ГК РФ. При этом моральный вред возмещается независимо от вины причинителя вреда в случаях, когда вред причинен жизни или здоровью гражданина источником повышенной опасности (ст. 1100 ГК РФ).

Отличительной чертой ответственности исполнителя является то, что он наряду с гражданской ответственностью также может нести уголовную, административную и дисциплинарную ответственность.

Уголовная ответственность исполнителя может наступить по ч. 2 ст. 109 Уголовного кодекса Российской Федерации (далее - УК РФ) (причинение смерти по неосторожности вследствие ненадлежащего исполнения лицом своих профессиональных обязанностей); по ч. 2 и 4 ст. 118 УК РФ (причинение тяжкого или средней тяжести вреда здоровью вследствие ненадлежащего исполнения лицом своих профессиональных обязанностей); по ч. 4 ст. 122 (заражение ВИЧ-инфекцией вследствие ненадлежащего исполнения лицом своих профессиональных обязанностей); по ст. 124 (неоказание помощи больному); по ст. 125 (оставление в опасности).Ответственность за незаконное оказание медицинских услуг наступает по УК РФ в случаях незаконного предпринимательства (ст. 171); незаконного занятия частной медицинской практикой или частной фармацевтической деятельностью (ст. 235); выполнения работ или оказания услуг, не отвечающих требованиям безопасности (ст. 238).

Ответственность исполнителя наступает по Кодексу РФ об административных правонарушениях (далее - КоАП РФ) в случаях незаконного занятия частной медицинской практикой, частной фармацевтической 
деятельностью либо народной медициной (целительством) (статья 6.2.); осуществления предпринимательской деятельности без государственной регистрации или без специального разрешения (лицензии) (статья 14.1.); продажи товаров, выполнения работ либо оказания населению услуг ненадлежащего качества или с нарушением санитарных правил (статья 14.4.); продажи товаров, выполнение работ либо оказание услуг при отсутствии установленной информации либо без применения контрольно-кассовых машин (статья 14.5.); обмана потребителей (статья 14.7.); нарушения иных прав потребителей (статья 14.8.).

Кроме того, непосредственный исполнитель (медицинский работник) несет дисциплинарную ответственность, например, за разглашение врачебной тайны.

Условиями возникновения деликтного обязательства являются: а) противоправное действие (бездействие); б) наличие вреда; в) причинная связь между противоправным деянием и вредом; г) вина причините ля вреда. Состав деликта может быть усеченным, когда закон исключает из него один элемент вину. В ряде случаев деликтная ответственность наступает в отсутствие вины причинителя (ст. 1079, 1095 ГК РФ).

Безвиновная ответственность является исключением из общего принципа ответственности за вину. Установление безвиновной ответственности тяготеет к областям деятельности, связанным с опасностью, риском. «Это привело, пишет Тихомиров А.В.,- к появлению в зарубежной правовой науке тезиса о том, что принцип вины как основания деликтной ответственности вытесняется понятием риска». Так, в германской доктрине и судебной практике сложилось понятие Gefahrdungshaftung- ответственность за опасность, а не вину.

Иначе говоря, ятрогенный деликт имеет место при необоснованном риске.

В литературе также выделяется термин «врачебная ошибка». «Врачебные ошибки»- это следствие добросовестного заблуждения врача при выполнении им профессиональных обязанностей». Главное отличие ошибки от других дефектов медицинской деятельности - исключение умышленных преступных действий, небрежности и халатности.

Врачебная ошибка это дефект оказания медицинской помощи, связанный с неправильными действиями медицинского персонала, характеризующийся добросовестным заблуждением при отсутствии признаков умышленного или неосторожного преступления.

В литературе ведутся споры об ответственности медицинских работников за врачебные ошибки. Высказываются три основных мнения по данному вопросу. В первом случае предлагается полное освобождение медицинских работников от ответственности за врачебную ошибку. Второй взгляд на проблему прямо противоположен - его сторонники отстаивают принцип безвиновной ответственности. И третья точка зрения, наиболее приемлемая, предлагает освобождение от ответственности при наличии объективных факторов врачебной ошибки и ответственность при субъективных факторах. 
Таким образом, исполнитель в силу особенностей предмета договора возмездного оказания медицинских услуг несет повышенную ответственность, характеризующуюся следующими признаками:

безвиновная (объективная) ответственность за причинение вреда при оказании медицинских услуг;

помимо гражданско-правовой исполнитель несет административную, дисциплинарную и уголовную ответственность (дисциплинарную, уголовную ответственность несет медработник, административную - как юридическое, так и физическое лицо, а гражданско-правовую - исполнитель по договору, то есть медицинская организация).

исполнитель несет договорную (за неисполнение или ненадлежащее исполнение договора) и деликтную (за причинение вреда во время исполнения договора) ответственность. 


\section{Литература}

1. Акопов В.И. Медицинское право в вопросах и ответах. - М.: ПРИОР, 2010. - C. 174-175.

2. Доголь Е.В. Медицинская ошибка в гражданском праве российской федерации // в сборнике «Юридические науки: проблемы и перспективы: Материалы IV Международной научной конференции», 2016. - С. 163.

3. Дроздова М.Е. Оказание платных медицинских услуг населению. Учет и налогообложение. // Главбух. - 2009. - № 6. - С. 27.

4. Егизарова С.В. Особенности компенсации морального вреда при ненадлежащем оказании медицинской помощи // Юрист. - 2003. - № 10. - C. 49.

5. Мохов А.А., Мохова И.Н. Еще раз к вопросу о врачебной ошибке как медицинском и социально-правовом феномене. // Юрист. - 2014. - № 2. С. 52.

6. Тихомиров А.В. Вред от врачебных действий (ятрогенный деликт) // Здравоохранение. - 2000. - № 11. - С. 149-164. 